Relations industrielles

Industrial Relations

\title{
Bratton, John, Japanization at Work
}

\section{Bruce Spencer}

Volume 49, numéro 1, 1994

URI : https://id.erudit.org/iderudit/050927ar

DOI : https://doi.org/10.7202/050927ar

Aller au sommaire du numéro

Éditeur(s)

Département des relations industrielles de l'Université Laval

ISSN

0034-379X (imprimé)

1703-8138 (numérique)

Découvrir la revue

Citer ce compte rendu

Spencer, B. (1994). Compte rendu de [Bratton, John, Japanization at Work].

Relations industrielles / Industrial Relations, 49(1), 195-197.

https://doi.org/10.7202/050927ar

Tous droits réservés (C) Département des relations industrielles de l'Université Laval, 1994
Ce document est protégé par la loi sur le droit d'auteur. L'utilisation des services d'Érudit (y compris la reproduction) est assujettie à sa politique d'utilisation que vous pouvez consulter en ligne.

https://apropos.erudit.org/fr/usagers/politique-dutilisation/ 
in an HRM survey course that is aimed at students from other disciplines. The basic goal of matching closely the textbook to the course is achieved.

Denis Morin

Université Laval

Japanization at Work, by John BRATTON, London, Macmillan, 1992, 244 p., ISBN 0-333-54574-5

There has been a continual stream of schemes - Quality of Working Life (QWL), Team Concept, Quality Circles, Total Quality Management (TQM), Lean Production, Just in Time (JIT), Synchronous Manufacture, etc. - largely inspired by envy of Japanese production techniques, which have been designed to increase job satisfaction for workers and cut company costs. One emphasis is derived from the realization that, in traditional companies, once at work many employees have little control over how they spend their time and that employers are not very interested in what workers think. The other stems from the need to meet the competitive challenge, to match Japanese management techniques, and generally to cut out "waste".

This renewed focus on human resources is helping to redefine human resource management as central to organizational success. The initial concerns of manufacturing companies have spread to service companies and public sector organizations. Consultants abound spreading this new gospel; managers are redefined as "leaders" and "coaches", workers as "associates" or "members", and factories and offices as "learning organisations".

Some of the writing in this area stems from a belief that we are now living in a "post-industrial society", and that "Fordist" mass production techniques based on Frederick Taylor's "scientific management" approach to work organization is no longer appropriate. For some authors adversarial union attitudes are also seen as inappropriate in this perceived new climate. "Toyotarist" production methods are sometimes contrasted and are depicted as collaborative and using "cell" production techniques rather than the assembly line; claims are made that production is more differentiated than it was previously with companies competing more on quality than price.

Although there has been a shift away from mass production techniques and industry, and an extension of service employment together with a move towards smaller production units, many of the jobs in both services and industry remain repetitive, largely unchallenging, and are low paid (for example employment in fast-food outlets - often referred to as "Mac-jobs" - are low skill and low paid part-time jobs). Therefore this shift to post-industrial society and towards new participatory management styles is overstated.

There have been a number of reports of companies' successful conversion to this new management style (for example the regular features in the Globe and Mail); reports, often supplied by consultants, emphasize how workers have greater control over the design of their job, how they are contributing much more to the organization, where 
there has been reduced absenteeism and major cost savings. But there have also been other, more independently authored, reports of companies which have had to amend their initial enthusiasm as economic conditions have worsened, with workers being laid off and TQM abandoned. Some companies which adopted these new human resource strategies, and have been operating them for some time, have still gone bankrupt in the recent recession.

Some of the more careful research, including work undertaken in Canada and Briton, has shown mixed results from adopting QWL, team concept and other similar concepts. In some cases workers who have accepted greater responsibilities have not been found to have gained greater control over time and work. In others, workers enjoyed some job rotation but generally did not believe they were gaining new skills, and although management did listen to workers suggestions these often resulted in job intensification and speed-up.

Clearly, management who adopt these new techniques are seeking to enlist workers' knowledge, ingenuity and cooperation to cut waste and compete more successfully. Some management are also hoping to turn workers away from unionization and to bind workers to company objectives. Although workers can gain greater job satisfaction, in the right conditions, from some of these human resource management policies, it is an exaggeration to describe all of these as simply "win-win" policies in which workers gain as much as employers. Many workers find that unionization remains a more satisfactory way of attempting to democratize the workplace and ensure their voice is heard and their rights protected.

John Bratton's important contribution to this burgeoning literature is to demonstrate that the market conditions and methods of production are crucial to the "success" of new managerial practices. Companies which enjoy a market niche and batch production methods utilizing skilled workers fared better than those competing in a more competitive mass production market. In the right conditions there could be enhanced job security, enhanced skills, and employee satisfaction, but there could also be job losses for less skilled workers, speed-up and dissatisfaction.

He does this via detailed case study analysis of 11 companies operating in the UK (8 small-batch production, 3 large-batch), undertaken alongside a mail survey of 419 establishments. As John explains the case study approach allows a researcher to test survey responses; " to observe changes in how the labour process is organised" (p. 13); and to gain information from other sources than management (who usually fill in the mail questionnaires). For Bratton the major advantage of the methodology was to gain an in-depth understanding of the lived experience of the organisations studied.

Chapter 2 provides an excellent introduction to the "Perspectives on Japanization" related to new technologies, and although principally drawn from UK literature, would serve Canadian students well. Next comes a discussion of labour unions' responses to change: that is followed by a chapter which situates the changes occurring in the engineering labour process in the context of Thaterchite Britain. Detailed case studies of 3 companies are reported in separate chapters: drawing evidence from managers, shop stewards and workers the labour process is explained. A concluding chapter 
draws together the theoretical and empirical work and the implications of the findings are discussed - for example the relationship between change and union power.

John Bratton, who now teaches in Kamloops, BC, would, understandably, be first to argue his findings are relevant to similar changes occurring in Canada, and he would be right to do so. Union density and workplace union attitudes are sufficiently similar to set Bratton's work alongside that of Canadian studies of the impact of new management techniques, and indeed he sets a high standard for this type of labour relations research. This book will be useful to all those who are trying to understand the impact of the changes taking place at work, and to those who wish to gain a better understanding of the UK industrial relations tradition of case study research.

Bruce SPENCER

Athabasca University

Transfer of Training: Action-Packed Strategies to Ensure High Payoff from Training Investments, par Mary L. BROAD et John W. NewstroM, Reading, Massachusetts, Addison-Wesley Publishing Company, Inc., 1992, 194 p., ISBN 0-201-19274-8

Comment justifier un programme de formation professionnelle qui ne contribue pas à modifier les comportements des participants au travail ? Cette question renvoie à la problématique du transfert des compétences acquises en milieu de formation vers l'application en milieu de travail. En outre, elle justifie la quête de moyens pour améliorer la performance individuelle au travail et le retour sur les investissements en formation professionnelle.

Broad et Newstrom tirent profit de cet engouement récent envers le transfert des compétences professionnelles. Ces auteurs ont recours à la littérature professionnelle, aux recherches empiriques et à la pratique pour identifier un nombre impressionnant de stratégies de développement des ressources humaines visant à améliorer la performance au travail. À notre connaissance, Transfer of Training représente le premier livre, sinon le seul, ayant comme principal objet la description d'un ensemble de réponses innovatrices au défi du transfert des compétences du milieu de formation au milieu de travail.

Dans la première partie du livre, intitulée Laying the Groundwork, les auteurs introduisent la problématique du transfert des compétences. On y retrouve la justification économique du thème (« gain greater payoff from training dollars »), l'évolution du rôle des professionnels en développement des ressources humaines et les barrières au transfert des compétences. Mise à part l'emphase sur le développement d'un partenariat entre les apprentis, les formateurs et les gestionnaires, cette première partie du livre ne présente rien de fondamentalement nouveau.

La seconde partie du livre, intitulée Identifying Transfer Strategies, présente une description détaillée des stratégies de transfert des compétences. Tout comme l'ont fait Wexley et Latham en 1991 dans Developing and Training Human Resources in Organisations, Broad et Newstrom ordonnent les stratégies selon qu'elles s'appliquent avant, pendant ou après la formation. Par exemple, avant la formation, on propose aux 